\title{
SOCIAL SECURITY ISSUES OF WORKERS IN INDIA DURING COVID 19 PANDEMIC
}

\author{
Dr. Kavita Solanki \\ Assistant Professor, University School of Law \& Legal Studies, Guru Gobind Singh Indraprastha \\ University, Dwarka-75, New- Delhi
}

DOI: 10.46609/IJSSER.2020.v05i10.014 URL: https://doi.org/10.46609/IJSSER.2020.v05i10.014

\begin{abstract}
Social Security as a concept is as old as the history of mankind in this world. With advancement in time and with change in the society, social security as a concept started devolving and developing through every phase of life. The concept social security itself is very wide and cannot be put into simple words and it mean different things for different strata of the society. Social security is an ideal that all welfare states aims to achieve for its society. It is such a dynamic concept that it keeps on evolving and changing as per the time and need of the society.

Social security for the workers however remains an unsolved problem It remains unsolved issue because a concept which is in existence since time immemorial has still not achieved its potential on the ground. The workers of the unorganized sector i.e. the sector that makes up the major proportion of the total workforce still remain exposed to the contingencies of life and are still not ensured without adequate social security cover. The legislature, prior to independence and even after independence has enacted several legislations to ensure social security to the workers. Some of these legislations have proved to be successful on the ground, whereas some of them are still toothless tigers with no practical feasibility.

The study of social security becomes all the more relevant during times of crisis, like the COVID-19 pandemic. The pandemic has affected every sector of the economy and have pushed the workers, especially the workers of unorganized workers who live on daily wages, at the verge of starvation. The present study, thus aims to analyze the social security legislations, to trace the references of social security in five year Plans and in the Constitution of India and suggestions for effective social security system.
\end{abstract}

Keywords: Five year plans, pandemic, social security, unorganised sector. 


\section{International Journal of Social Science and Economic Research}

ISSN: $2455-8834$

Volume:05, Issue:10 "October 2020"

\section{INTRODUCTION}

Unfortunately, Social security as a subject remained ignored in India. The development in this area more or less remained confined to labour welfare. Although, the right to social has been recognized under important declaration and covenant, ${ }^{i}$ yet majority of human rights mechanism and instruments have remained silent over its definition and its acceptance. The subject of social security is both wide as well as narrow. Authors, scholars and social scientist have used the term without due weightage or emphasis on its definition. Social security is a concept of social welfare that aims to provide social protection against various contingencies like poverty, unemployment, old age, death etc. The term social protection and social security has however been used interchangeably. It is used widely, while referring to various social welfare schemes and it is used narrowly while referring to schemes that are titled social security.

\section{CONCEPT}

Around 60 years ago, Arthur Altymer, the then chairman of United States Social Security Board (USSSB), made an important observation about social security he said: "Social Security is to the interest of all other countries, it contributes to political stability, economic well-being, and is the embodiment of belief in the innate dignity and worth of the common man. The development of social security programs is essential both to the internal security of nations, and to the international security and peace of the world". ii

\section{COMPONENTS OF SOCIAL SECURITY}

The system of social security across globe consist of mainly two important components:

(a) Social Insurance and (b) Social Assistance.

a) Social Insurance Programme

i. These are contributory in nature and are thus financed by contributions.

ii. Earned Benefits are made available to the workers and his/her family.

iii. They are usually provided to cover various contingencies that hamper the earning or the earning capacity such as: sickness, maternity, Layoffs etc.

b) Social Assistance Programme 


\section{International Journal of Social Science and Economic Research}

ISSN: $2455-8834$

Volume:05, Issue:10 "October 2020"

i. These programs are non contributory in nature and are financed through general revenues.

ii. These programs are formulated to help the vulnerable groups like the, disabled, elderly or the children by supplementing their income. These programs also as a "safety net" for those who can't avail the social Insurance programs.

iii. The benefits under these programs can either be in cash or in kind in the form of free ration, free education etc.

\section{DEFINITIONS}

A lot many institutions and scholars have tried to define and explain the term social security. However, the term social security cannot be put into a straight jacket formula and hence there is no single universally accepted definition. The term social security can be used to denote specific government scheme or policies that are aimed to prevent want by providing basic means to the families and the society so as to ensure their subsistence. Social security as concept is largely base on the notions of social justice and human dignity.

- LABOUR CODE ON SOCIAL SECURITY, 2018: The code defines social security as "the measures of protection afforded to worker to ensure access to health care and to provide income security, particularly in cases of old age , unemployment, sickness, invalidity, work injury, maternity or loss of a bread winner by means of rights enshrined and schemes framed under the Code" iii

- REPORT OF THE NATIONAL COMMISION OF LABOUR, 1969: Social security envisages that the members of a community shall be protected by collective action against social risks causing undue hardship and privation to individuals whose private resources can seldom be adequate to meet them. ${ }^{\text {iv }}$

Thus the national commission envisages social security as a tool to cover certain risk for which a person with limited means cannot provide for. Also, as per the above contribution for the country's wellbeing shall be afforded protection during contingencies that he may experience over his lifetime.

\section{- INTERNATIONAL LABOUR ORGANISATION}

The ILO since its inception has been working in the domain of social security. It defines and explains Social security as "the protection that a society provides to individuals and households 
International Journal of Social Science and Economic Research

ISSN: 2455-8834

Volume:05, Issue:10 "October 2020"

to ensure access to health care and to guarantee income security, particularly in cases of old age, unemployment, sickness, invalidity, work injury, maternity or loss of a breadwinner".

According to the ILO resolution on Income Security, ${ }^{\text {vi }}$ the social security is to be provided during following contingencies: sickness, unemployment, injury, maternity, old age, Invalidity, Emergency Expenses. However, a subsequent Convention ${ }^{\text {vii }}$ further added family benefits and medical care to the aforementioned list and removed emergency expenses as contingencies.

- FRIED LANDAR: Fried Landar has defined social security "as a policy of protection that a society provides against certain contingencies that a person may experience during this modern life like s ickness, old age, accident, unemployment and against which the person cannot protect himself by his foresight or own ability". viii

- CAMBRIDGE DICTIONARY: "A system of payments made by the government to people who are ill, poor, or who have no job." ix

- MERRIAM WEBSTER: "The principle or practice or a program of public provision (as through social insurance or assistance) for the economic security and social welfare of the individual and his or her family."x

\section{DEVELOPMENT OF SOCIAL SECUIRTY DURING FIVE YEAR PLAN -POST INDEPENDENCE}

Post Independence, it was felt that the labour policy of the country shall aim to satisfy the basic needs of workers/employees like shelter, food, clothing etc. The process of economic development in India thus began with First Five year plan in April 1951. ${ }^{\mathrm{xi}}$ In order to further the objective of the constitution and to fulfill the duty mandated upon the state qua the welfare of labour, planning was introduced to bring in directions that would be aimed at social, moral, economical and physical improvements of the labour.

\section{- FIRST FIVE YEAR PLAN (1951-1956)}

It was introduced in the year 1951 and had two main aims i.e. Social justice and improved quality of life. These objectives were brought in from the principles and directives enshrined under Part IV of the constitution and reflect the ideals of the community. According to the first year plan, adequate provisions shall be incorporated to satisfy the basic needs of the workers so as to ensure the health and well being of the workers. The basic necessities that it aimed to satisfy were clothing, shelter and food. 


\section{International Journal of Social Science and Economic Research}

ISSN: $2455-8834$

Volume:05, Issue:10 "October 2020"

Further, it also highlighted that the workers shall be provided there due share of economic and social contribution in the form of social security provisions, better healthcare facilities and increase cultural and recreational activities. ${ }^{\text {xii }}$ While observing great inequalities between the level of income and the urban and rural areas, it was observed that these inequalities in the society are both uneconomical and unjust. The object that was thus sought to be achieved was of a more equitable wealth distribution. The plan highlighted various legislative and fiscal methods to achieve this utopian goal. One of the method that the plan suggested to diminish this inequality was to raise and improve the standard of living of the vulnerable section through improved production capacity and increase of wealth in the community as a whole. The plan further noted that it is not just the mere wages through which a worker is satisfied, a worker also expects to be secured against all types of risk including natural and those arising out of employment. xiii

\section{- SECOND FIVE YEAR PLAN (1956-1961)}

During this plan the state adopted a socialistic pattern and hence this plan further propounded the importance and essence of socialistic pattern of society. Considering the socialistic pattern, the plan noted that the line of development shall not be based on profit motive alone, but also on social gain. And, the result should not merely be an increase or improvement in the national income but also in reduced inequalities of wealth. The plan emphasized that the benefits of the development shall accrue more to the vulnerable section of the society or the less privilege class and efforts shall be made to diminish the concentration of economic power and wealth. ${ }^{\text {xiv }}$ It was pointed out in the plan that the worker's right to fair wage which although has been acknowledge, is not present in the practical arena. ${ }^{\mathrm{xv}}$ Therefore, it was suggested in the plan to raise the real wages of the workers through a wage policy. Amongst various things suggested in the plan to achieve the said object, the plan suggested that blanket of Employee Provident Fund to be extended so as to cover more establishments. It also suggested amalgamation of various social security scheme under one umbrella. ${ }^{\text {xvi }}$

The plan further emphasized on the conditions of women workers and the effective implementation of legislations which provided maternity benefits, protection against injury and crèche facilities at workplace. ${ }^{\text {xii }}$ The plan also focused on the conditions of agricultural workers and noted that during turbulent economic conditions such agricultural workers need immediate and special attention so as to raise their standard of living. ${ }^{\text {xiii }}$

\section{- THIRD FIVE YEAR PLAN (1961-1966)}

This plan highlighted the importance of social assistance programmes in India. ${ }^{\text {xix }}$ The plannoted the following :"It would be desirable to make a modest beginning in respect of three groups of 


\section{International Journal of Social Science and Economic Research}

ISSN: $2455-8834$

Volume:05, Issue:10 "October 2020"

persons, the physically handicapped, old persons unable to work and women and children, where they are altogether lacking in the means of livelihood unsupport. Assistance for them will have to come from voluntary and charitable organisations, municipal bodies, panchayat samitis and panchayats and voluntary organisations. With a view to enabling these organisations to develop their activities with the help of local communities and giving them a little support, it might be useful to constitute a small relief and assistance fund". ${ }^{x}$

With respect to social security for workers, this plan suggested for creation of special welfare fund for workers working in industries such as mica and mining. The plan also suggested that since these funds are required to meet needs of the workers, thus iron and manganese ore were also proposed to be brought in the ambit of welfare funds. The plan also stated that the state and local bodies shall take proactive steps in the formation and implementation of various social security and social assistance schemes.

\section{• FOURTH FIVE YEAR PLAN (1969-1974)}

The fourth year plan expanded the scope of employee state insurance facilities by including hospitalization to all family members of insured workers employed in commercial shops and establishments. It also provided for the extension of this benefit to the non power factories employee. ${ }^{\text {xxi }}$

The plan also emphasized that programmes like holiday homes, welfare center and recreational homes shall be incorporated by the states. The plan further stressed on strengthening and improving the effective administration of labour law. ${ }^{\text {xii }}$

\section{• FIFTH FIVE YEAR PLAN (1974-1979)}

The fifth year plan stated that the progress of socials security measures is relatively stray. It thus emphasized that the suggestions of the committee appointed by Employee State Insurance Corporation (ESIC) shall be implemented. ${ }^{x x i i}$ The suggestions involved carrying out a phased programme for five years with extension of such measures to various establishments including mines and smaller shops. It also reiterated the need to integrate various social security measures under one roof. ${ }^{\text {xiv }}$

\section{- SIXTH FIVE YEAR PLAN (1980-1985)}

The sixth five year plan appreciated the progress of social security schemes. The plan suggested extension of provident fund scheme to even smaller establishments and in rural areas. ${ }^{\mathrm{xxv}}$ The plan 


\section{International Journal of Social Science and Economic Research}

ISSN: $2455-8834$

Volume:05, Issue:10 "October 2020"

suggested removal of financial difficulties that states encounter while implementing laws. One of the suggestion given in the plan was to integrate welfare and

social security schemes in areas where they overlap, for instance: Income security and medical care during contingencies like disability, sickness or death. The object behind this suggestion was to increase the efficiency and to save resources. ${ }^{\text {xxvi }}$

The plan emphasized that special schemes needs to be developed for the benefit and advantage of vulnerable workers such as artisans, hand loom weavers, leather workers, fisherman and agricultural labour by the state governments. ${ }^{\text {xxvii }}$ It was also noted in the plan that the government shall take steps to abolish bonded labour and child labour. ${ }^{\text {xxviii }}$

The plan further focused on protection of women workers and prohibition child labour in various hazardous industries and mines. It observed that the state government shall take steps to improve social security measures and improve welfare by providing facilities such as crèche, maternity benefits and equal pay for equal work. ${ }^{\text {xxix }}$

\section{- SEVENTH FIVE YEAR PLAN (1985-1990)}

This plan is one of the significant plans for the from labour law perspective as it stressed about the workers in the unorganized sector. The plan highlighted the plight of the labours of unorganized sector and noted that social security schemes needs to be developed for workers working in the unorganized sector in both rural and urban areas. It observed that in unorganized sectors the workers are deprived of their income due to lack of proper legislations and rules in place. The plan, however, highlighted the need of creating policies to increase employment opportunities and income generation in unorganized sector, especially in rural areas. While dealing with the problems of unorganized sector workers, the plan also stressed upon the problems of workers in rural areas especially beedi workers, handloom workers, leather workers, etc. ${ }^{\mathrm{xxx}}$

\section{• EIGHTH FIVE YEAR PLAN (1992-1997)}

The plan highlighted that social security benefits like safe and humane conditions of work and adequate level of earnings which are minimum social security measures are the major contributors that will enhance the quality and standard of life of these workers. The plan also noted that the Minimum Wages Act has not been adequately implemented and covered. The plan however applauded the National Child Labour Programme which was formulated to prevent child labour. The plan stressed upon the importance of education and suggested states to impart 


\section{International Journal of Social Science and Economic Research}

ISSN: $2455-8834$

Volume:05, Issue:10 "October 2020"

education to workers and labourers so as to make them aware about the legislations, the social security measures and benefits and the grievance redressal programmes.

- NINTEH FIVE YEAR PLAN (1997- 2002)

This plan highlighted the need to create conditions for provisions for social security and to improve labour productivity. These two aspects would help in supplementing the labour market. It was also pointed out that the problem of surplus labour coupled with the issue of unorganized workers led to the increase of unhealthy labour practices such as child labour, bonded labour etc. The plan stressed on the need to develop programmes and to focus resources on skill development, creation of industrial harmony, information exchange and insurance against various contingencies. ${ }^{\mathrm{xxxi}}$

The main aim of the plan was to ensure social security at places where there are large number of unorganized workers and high degree of poverty. The plan had a dual aim, one was to provide employment generating programmes and another one was to create provisions that provide for bare minimum needs like housing, food, clothing, education etc. ${ }^{\text {xxii }}$

\section{- TENTH FIVE YEAR PLAN (2002-2007)}

The tenth five year plan noted that for prosperity and effective functioning of enterprises, productivity of labour becomes an essential factor and thus it needs to be improved. Amongst other factors responsible for increasing labour productivity, the plan noted that dignity of labour, attitude of society towards labour and work is equally important in improving and influencing the labour productivity. ${ }^{\text {xxxiii }}$

The plan aimed at securing social and economical objectives through a set of policies and measures in labour market. The plan also noted that adequate working conditions are ensured at workplace by minimizing occupational hazards and by promoting safety, and reasonable return on labour is also ensured by regular and timely payment for fair wages to the workers and with social security provisions. ${ }^{\text {xxiv }}$

The plan raised a concern over the situation where there is increase in the the supply of labour as compared to the demand, which in turn leads to unhealthy labour practices such as bonded labour, child labour etc. The plan noted that the rate of increase in working population has been at a higher pace than the average population and the number of workers in agriculture sector has also declined. The plan therefore suggested that an effective implementation of schemes and legislations to address and monitor such problems is needed. It also stressed upon opening new avenues for employment, especially in agriculture and allied sectors such as poultry, horticulture 


\section{International Journal of Social Science and Economic Research}

ISSN: $2455-8834$

Volume:05, Issue:10 "October 2020"

etc. The plan highlighted the need of organized sector to absorb the increase in labour supply as well. ${ }^{\mathrm{xxxv}}$

\section{- ELEVENTH FIVE YEAR PLAN (2007-2012)}

The eleventh five year plan noted that the unorganized units under the agricultural sector like fishing, forestry, live stock, etc. are not protected under social security legislations nor are the working conditions regulated under any law. The plan, thus reiterated the findings of National Commission for Enterprises, that law providing social security benefits and regulating the minimum standard and conditions of work needs to be enacted for the agricultural workers and small farmers in the unorganized sector. The plan stressed upon the need of having an inclusive system of social security for the India's $90 \%$ workforce, majority of which works in unorganized sector. ${ }^{\text {xxxvi }}$ However, the plan also highlighted that barring few states, a large number of states in India do not provide any social security cover to people working in unorganized sectors. It was also pointed out that the existing social security schemes that are in place cover only a mere 5$6 \%$ of the total workers working in informal sector. The plan thus suggested that there shall be adequate and efficient dispute resolution mechanism and social security advisory boards so that the workers may claim what is due to her/him. It was also noted that statutory package for social security shall be ensured to all the unorganized workers. In respect of health facilities, the plan highlighted the National Rural Health Mission and its relevance to provide affordable, accessible and quality health services to people in rural areas. The plan also contended that it is necessary for the state and establishments to provide living wages and not basic wages to workers, so as to guarantee decent standard of living to them. Therefore, the Eleventh Five Year Plan had dual objectives, the first being the need of social security for the unorganized sectors and second being the treatment of social security as a wide and inclusive concept that covers sanitation, health, housing, cultural and educational benefits During this period, after the recommendations of various committees and commission, Unorganised Workers Social Security Act, 2008 was passed to ensure welfare and social security benefits to workers.

\section{• TWELFTH FIVE YEAR PLAN (2012-2017)}

The Twelfth plan focused and stressed upon the women working in rural and unorganized sector and thus noted as follows: "Women in the unorganized sector require social security addressing issues of leave, wages, work conditions, pension, housing, child care, health benefits, maternity benefits, safety and occupational health, and a complaints committee for sexual harassment. This can only be ensured in extending labour protection to these sectors in a manner that pays special attention to the needs of women workers". xxxvii 


\section{International Journal of Social Science and Economic Research}

ISSN: $2455-8834$

Volume:05, Issue:10 "October 2020"

The twelfth plan also highlighted the significance of promoting self employed workers ,home based workers and small producers for the overall development of nation. These sectors were an essential component of this plan as women constitutes a significant portion of workforce in such sectors. The plan thus suggested setting up facilitation and facility centers for such enterprises so as to impart training, information and develop relevant skills. ${ }^{\text {xxxviii }}$

The plan suggested amendment and modifications in various schemes like Medical Insurance policies, Pensions, retirement benefits etc., so as to mould them in such a way so as to cater to the need of women. It further proposed that the credit facility for the women shall be improved by issuing Kisan Credit cards, affordable loans for women entrepreneurs. ${ }^{\text {xxxix }}$ The plan also stressed on improving and developing skills for women workers and entrepreneurs so as to promote participation of women in workforce. ${ }^{\mathrm{xl}}$ With respect to migrant women workers, the plan suggested to facilitate direct transfer of funds to promote savings and easy portability of ration cards. Migrant Assistance Centres were also suggested to be set up so as to provide information, counselling and placement to migrant workers. ${ }^{\text {xli }}$

- THREE YEAR ACTION AGENDA (2017-2020) $)^{\text {xlii }}$

In 2015, the NITI Aayog, a government think tank came into existence and it was felt that the tools for development process needs to be restructured and hence the Twetlth Five year plan was the last One. The Government think tank thereafter started coming up with 3 year action agenda. The government under its first three year plan, aims to incur an expenditure of more than Rs. 2000 crores each year for the next three year on social security sector. The plan noted that underemployment is a bigger problem than unemployment as a result of which the workers that are employed are stuck in low wages job. Thus, the plan suggested that the aim should be to create more well paying jobs in the formal sector. The plan also suggested that the since a large part of India's population resided in rural areas, the goal should therefore be, to shift rural workers to nonfarm sectors through improved skill development programmes. The plan also stressed on the need of giving adequate attention to persons with disabilities. The plan notes that due socio- economic empowerment has not been provided to them and thus several policy, legislative and institutional reforms are to be formulated and implemented. The plan highlighted the need of improving access to educational, employment and healthcare facilities to persons with disabilities. The plan also addresses the need of providing livelihood to urban poor through Deen Dayal Antodaya Yojana. This National Urban livelihood mission aims to develop opportunities for skill development so as to empower the urban poor for market based employment or self employment projects. The plan further noted that schemes like Pradhan Mantri Awas Yojana is a step in the right direction to provide the basic necessity for affordable housing to the weaker section of the society. 
International Journal of Social Science and Economic Research

ISSN: 2455-8834

Volume:05, Issue:10 "October 2020"

\section{SOCIAL SECURITY LEGISTATION FOR WORKERS - AN INDIAN PERSPECTIVE}

A well developed social security not only fulfills and furthers the constitutional goals of social and economic justice, but also aids in maximizing production and thereby contributing to the development of nation's GDP. These measures also help state in achieving the directive principle of being a welfare state by substantially improving the working and living conditions of the workers.

Prior to independence, the social security regime was not so developed as the British Government did not emphasize much on the well being and welfare of workers. However, two important legislations that were in existence even during the British rule in India were the Workmen Compensation Act ${ }^{\text {xliii }}$ and the Fatal Accident Act. ${ }^{\text {xliv }}$ These legislation provided some limited degree of social security during the pre independence era against contingencies like accident or any mishappening. However, post independence the Government started ramping up its social security regime. Following are some of the important laws dealing with social security in India:

\section{EMPLOYEE COMPENSATION ACT, 1923}

Due to increased industrial and economic activity, the life of workers has been now under more risk. This legislation is in the favour of workers and employees as employers are put under legal obligation to pay compensation in case of work related injuries or death. In case of death, the compensation is paid to the family members of the deceased without delay. ${ }^{\text {xlv }}$ The main object of the legislation is however to prevent accidents from happening and to make employer more aware and careful about the health of his workers. The Act has a wide coverage as it covers workers of various sectors and even agricultural and casual workers. The Act also provides notional extension with regard to time and place and thus the worker can avail the benefit even if he was not at the employer's premise during the time of accident. .lvi

\section{Advantages -}

The victim employee or his/her family members are paid compensation in cash during any injury or death due to "injury arising out of or in the course of employment" or occupational disease. ${ }^{\text {xlvii }}$ The compensation so payable is determined after taking into consideration the injury, monthly wage, earning capacity and relevant factors. Post 2010, the legislator allowed medical expenses to be paid to workers irrespective of the wage ceiling. Unlike social insurance, the benefit under this act is available to the workers without him making any contribution as the employer himself is liable to pay compensation. 
The legislation also contain provision for the dependents of the worker and it states that in case of injury leading to disablement or death, the employer shall pay compensation to the dependent family of the worker so as to ensure their survival.

\section{EMPLOYEES' STATE INSURANCE ACT, 1948}

It is a significant social security scheme of the country that provides social insurance to the employees. The objective of the legislation is to make certain benefits available to the insured workers when they face contingencies like maternity, sickness or employment related injury. The law is made applicable to all factories and industrial establishments including government undertakings but would not include seasonal factories where manufacturing process is being carried out by 10 or less people. xlviii Various State Government have made the ESI Act applicable to other classes of establishments as well such as newspaper establishments, cinema etc. ${ }^{x i x}$ The schemes and the benefits under the act are financed through contribution and subscriptions paid by employees, employers nad through grants and donations by Government or other bodies. The working of these benefits are governed and administered through a multi partite organization known as the Employee State Insurane Corporation. The organization consists of nominees of state and central government and representative of employees and employees. The Act also empowers the Employees State Insurance Corporation (ESIC) to bring in new social security and welfare measures for the insured workers. ${ }^{1}$ Therefore, during tragic times like the present COVID-19, it becomes both legally and morally imperative on the ESIC to use its statutory powers and to utilize its existing corpus so as to minimize the catastrophic impact of COVID19.

\section{Advantages -}

The ESI legislation provides a wide array of benefits to the insured workers. Following are some of the benefits

\section{Sickness Benefit}

Under this law, cash benefits are to be provided to every subscriber or insured worker during his period of sickness. The person shall receive such benefit only after the certification by a duly appointed medical practitioner and shall carry out all instructions and advices of the medical officer.

\section{Maternity benefit}


International Journal of Social Science and Economic Research

ISSN: 2455-8834

Volume:05, Issue:10 "October 2020"

Cash benefit shall be provided to all insured woman workers in case of any pregnancy related contingencies such as miscarriage, confinement, premature birth of child, medical termination of it or any sickness related to pregnancy. ${ }^{\text {li }}$ Such a benefit is made available only if the women worker abstains from working during that period. ${ }^{\text {lii }}$

\section{Disablement benefit}

Disablement benefits are payable in cash installments to an injured employee who sustained those injuries during "the course of his employment" and as a result of such injury, the worker has become temporary or permanently disabled or has contacted any diseases termed as occupational disease under the III ${ }^{\mathrm{rd}}$ schedule of the Act.

\section{Dependent benefit}

The Act also provides for benefit in the form of pension to the dependent or the family members of the employee, in case of any injury resulting in disablement or death of the employee.

\section{Funeral Expenses}

The rules and regulations framed under the ESI Act allow for payment of funeral expenses, subject to a maximum of Rs. 10,000, 'iii to the eldest member of the deceased employee's family or to a person who incurred such funeral expenses after the employee's death. The claim for such death shall be submitted within three months from the date of death.

\section{EMPLOYEE PROVIDENT FUND AND MISCELLANEOUS PROVISION ACT, 1952}

Provident fund is a type of post retirement benefit and is contributory in nature as both the employees and employer contributes their share in the pool. The Act envisages to protect the the employee and his family in case of his retirement or early demise. The Act is made applicable to all those industries where more than 20 people are employed and is specified in Schedule I of the Act. The Central Government has established a fund in which both the employee and employer make an equal amount of contribution.

\section{Advantages -}

Three important schemes have been formulated under this legislation to ensure social security to the employees viz. the provident fund scheme ${ }^{\text {liv }}$ to open up provident fund account of the employees, the family pension policy ${ }^{\mathrm{lv}}$ to provide post retirement assurance, and the Insurance schemes for ensuring life insurance benefit. ${ }^{\text {lvi }}$ 
International Journal of Social Science and Economic Research

ISSN: 2455-8834

Volume:05, Issue:10 "October 2020"

\section{MATERNITY BENEFITS ACT, 1961}

The Maternity Benefit Act was enacted with an intention to enable women workers working in non seasonal establishments to discharge her family obligations and at the same time to ensure health of the woman and her child. The Act regulates the employment of female workers during pregnancy and after the child birth. In the absence, of the act the women workers would have been subjected to termination from employment due to absence on account of pregnancy. The Act has a wide coverage and it applies to all establishments, mines, factory, plantations etc.

\section{Advantages -}

This social security act provides a pregnant female worker with twelve week of paid maternity leaves. This 12 week can either be divided into 2 periods of 6 week each i.e. during pregnancy and after birth or the benefit can be availed entirely after the birth.

This twelve week period of paid leaves can be extended to maximum of one month as well, if the women suffer from any pregnancy related illness. The Act allows payment of medical bonus of Rs. 1000 in cash, in case of absence of pre natal or post natal care. The employer is barred from terminating, discharging or dismissing any women worker during the maternity leave period.

\section{PAYMENT OF GARTUITY ACT, 1972}

This social security legislation aims to provide another type of retirement benefit i.e gratuity. It is considered to be as a reward for efficient, good and faithful service to the organization for a period of time. The aim of this legislation was to ensure social security to workers working for a considerable period of time in certain commercial and industrial establishments. ${ }^{\text {lvii }}$ The act covers mines, plantations, factory, oilfields, shops and establishments and those establishments in which more than 10 person are employed. The amount is usually paid during retirement and in case of death of an employee, it is paid to the nominee. The working of this act is below satisfactory as its implementation depends upon the employer and the grievance redressal is not worker friendly.

\section{SOCIAL SECURITY PROVISIONS - UNORGANISED SECTOR PAYMENT OF WAGES ACT, 1936}

The act was enacted on the basis of recommendations received from the royal commission so as to mitigate the suffering of workers whose wages were delayed or were deducted. This Act aims to regulate and govern the payment of wages and to eliminate and prevent malpractices relating to payment to wages. The act extends to every factory, industrial and commercial establishment. 
International Journal of Social Science and Economic Research

ISSN: 2455-8834

Volume:05, Issue:10 "October 2020"

The working of the act has been criticized for its ineffective implementation as in the case of beedi workers, where the employer fraudulently deduct wages on the ground that the beedi so manufactured is not as per standard, but which actually is.

\section{Advantages -}

The Act cast a duty on the employer(s) to pay wages to his employees by a fixed period. .viii $^{\text {Tii }}$ The period shall, however, not exceed one month duration. The act further provides that the employer shall not make any deductions that have not been authorized under the act.

\section{MINIMUM WAGES ACT, 1948}

Prior to this law, there was no mechanism to regulate the wages for workers and thus they were exploited as they were not given their due share of wages. Hence, in order to address the issues of low wage and disparity in wages, particularly in unorganized sector, the need of formulating such legislation was felt. Hence, this law was passed with an objective to provide fixation of wages and its revision by the appropriate government. This Act also gives effect and furthers the international obligation of India to the 1928 ILO Recommendation. The Act places a reasonable restriction on the right of the employer prescribed under Article 19(1)(g) and furthers the DPSP enshrined under the Constitution. ${ }^{\text {lix }}$ The Act is made applicable on workers working in both agricultural and non agricultural sector and also include piece rated workers and home workers.

\section{Advantages -}

The act mandates the appropriate government to fix the minimum wages and to revise it from time to time for the workers working in establishments specified under Part I or II of the Schedule. The appropriate government may fixes the minimum wages of any scheduled employment where there are less than 1000 workers at its own discretion. ${ }^{\text {lx }}$ The government has been empowered to exercise its discretion for determining the minimum wages in case of piece work, time work, overtime and guaranteed time rate. ${ }^{\text {lxi }}$ The wage can be fixed at different rate for different people such as adolescent, adult, children etc. and it can be either on hourly, day, monthly basis. ${ }^{1 x i i}$

\section{BONDED LABOUR SYSTEM (ABOLITION) ACT, 1976}

The system of bonded labour, was deeply rooted in primitive society and especially in agricultural sectors. This act was thus enacted to prevent physical, social and economic exploitation of the vulnerable section of the society. The act has been successful in its implementation, as with change in social system and conditions the unfree status changed 
positively. However, there do exist some sectors where the bonded labourage is still prevalent. Moreover, the concept of bonded labourage has taken a new shape in the form of low wages and less freedom for vulnerable workers.

\section{Advantages -}

The labourers were discharged free and were freed from any obligation arising out of any instrument of bonded labourage. The liability of bonded labourers to repay their debt was extinguished. The Act also allowed setting free their property that was under mortgage.

\section{UNORGANISED WORKER SOCIAL SECURITY ACT, 2008}

This legislation was passed in response to the finding of the commission ${ }^{\text {lxii }}$ that there is lack of appropriate and comprehensive legislation regulating this sector and that even after several state government have formulated and implemented certain welfare measures for the welfare of this sector, the same has proved to be inadequate.

The objective of this legislation is to ensure welfare and to develop a social security regime for the workers of this unogranised sector. This legislation ensure a universal coverage for the most vulnerable section of the society as it covers a wide array of people including self employed worker, home based worker and daily wage workers. The interesting part of this act is that it covers those workers of unroganised sector that have not been covered by any of the existing legislation prescribed under Schedule II of this Act. ${ }^{\text {Ixiv }}$

\section{Advantages -}

The Act empowers the central and the state government to formulate and implement schemes of social security in following matters:

\begin{tabular}{|l|l|}
\hline \multirow{3}{*}{ Central Government } & Healthcare Benefits \\
\cline { 2 - 3 } & Old Age benefts \\
\cline { 2 - 3 } & Disability benefits \\
\cline { 2 - 3 } & Maternity benefits \\
\hline \multirow{2}{*}{ Provident Fund } \\
\hline & Housing \\
\hline
\end{tabular}


International Journal of Social Science and Economic Research

ISSN: 2455-8834

Volume:05, Issue:10 "October 2020"

\begin{tabular}{|l|l|}
\hline \multirow{3}{*}{ State Government } & Employment accident/injury \\
\cline { 2 - 2 } & Education \\
\hline & Skill Development \\
\hline & Funeral Assistance \\
\hline
\end{tabular}

\section{SOCIAL SECURITY CODE, 2019}

The social security code is one of the four proposed labour codes that the NDA Government proposes to introduce. This code is based on the recommendations of the Labour commission and aims at consolidating various other legislations relating to social security such as legislations on maternity leave, unemployment coverage, healthcare etc. The code aims to cover both sectors of workers i.e. unorganized and organized workers. This code will help make the existing legislations governing and regulating labour conditions, in sync with emerging socio economic conditions. It will also lead to universal coverage with reduction in complexity and technicalities. The code will lead to better compliance as the multiplicity of proceeding before various authorities will reduce.

\section{Advantages-}

The Government aims to provide various social schemes under one umbrella including EPS, EPF and EDLI schemes. The government aims to provide various other schemes such as the (i) ESI scheme for maternity, sickness etc. (ii)maternity benefits (iii) gratuity to worker employed for more than 5 years (iv) construction workers fund and (v) compensation in case of injury or occupational disease. The act states that except EPF, all other social security schemes shall be borne by the employer.

The Act also empowers the state government to formulate policies for gig workers i.e free lancers, platform workers and self employed workers, so as to extend social security benefits to these people as well. The scheme for such workers may be financed through contributory fund.

The act provides for stringent provision in the form of fines and imprisonment in case of failure on the the part of employer to make necessary contribution to the schemes and if there is any falsification or deceit in publishing the reports.

SOCIAL SECURITY AND THE INDIAN CONSTITUTION SOCIAL ORDER FOR WELFARE - ARTICLE 38 


\section{International Journal of Social Science and Economic Research}

ISSN: $2455-8834$

Volume:05, Issue:10 "October 2020"

Article 38 of the constitution casts a duty on the state to promote welfare of the people by ensuring and protecting a social order. The Article further reaffirms the preamble of the constitution by stating that the social order so ensured by the state shall provide justice- social, economical and political. Article 38 of the Constitution embodies the principle of distributive justice i.e. elimination of economic inequalities and thereby rectifying the resultant injustice in the society. ${ }^{\text {lxv }}$

An Amendment ${ }^{\text {lxvi }}$ was introduced in the said Article and a new directive principle was thereby introduced which consequently casted an additional obligation on the state to minimize and eliminate inequalities in the income, status, facilities and opportunities. ${ }^{\text {lxvii }}$ In Air India Statutory Corporation v. United Labour Union ${ }^{\text {lxviii }}$ the apex court explained the meaning of social justice under Article 38 of the constitution. The court said that "that the concept of social justice consists of diverse principles essential for the orderly growth and development of personality of every citizen. 'Social justice' is thus an integral part of justice in the generic sense”.

\section{SOCIAL SECURITY DIRECTIVES TO BE FOLLOWED BY STATE - ARTICLE 39}

Article 39 directs the state to follow certain principles while enacting legislations. Following are the directives prescribed under the Article:

- Adequate means of livelihood

- Distribution of control and ownership of material resources.

- Eliminating concentration of wealth.

- Pay parity for the work between male and females

- Protecting health and strength of worker and children and to ensure that economic necessity do not push them in avocations unsuited for them.

- Preventing exploitation of children and youth

In Randhir Singh v. Union of India ${ }^{\text {lxix }}$ the Supreme Court while dealing with Article 39(d) held that "Equal pay for equal work though not a fundamental right, is indeed a constitutional objective and can therefore be enforced through constitutional remedies". However, this objective of equal pay for equal work cannot be put applied stringently and -thus reasonable classification based on intelligible differentia is permissible.

In M C Mehta V. Union of India, ${ }^{\text {lxx }}$ also referred to as the Child Labour Abolition Case, a three judge bench of the supreme court held that a child below the age of 14 years cannot be employed in any hazardous industry or mines. The court also issued a slew of direction including setting up of a welfare fund for rehabilitation of such children and providing alternative employment for the 
International Journal of Social Science and Economic Research

ISSN: 2455-8834

Volume:05, Issue:10 "October 2020"

adult. This judgment had the effect of ensuring social security benefits to the children and the family.

\section{RIGHT TO WORK, TO EDUCATION AND TO PUBLIC ASSISTANCE - ARTICLE 41}

The Article 41 of the constitution directs state subject to its economic capacity, to ensure the people (a) Education (b) Employment and (c) Public assistance in case of contingencies like sickness, unemployment, old age, disablement etc.

\section{JUST AND HUMANE CONDITIONS - ARTICLE 42}

According to Article 42 of the Indian Constitution, the state shall make adequate provisions for just and humane conditions and shall also make provisions for maternity benefit. The Supreme court while upholding the contention of non regularized women employees for maternity relief, held that: "Since Article 42 specifically speaks of 'just and humane conditions of work' and maternity relief, the validity of an executive or an administrative action in denying maternity benefit has to be examined on the anvil of Article 42 which, though not enforceable at law, is nevertheless available for determining the legal efficacy of the action complaint of."1xxi

\section{LIVING WAGES OF WORKERS - ARTICLE 43}

Article 43 of the Constitution of India provides for living wages to the workers. The Article requires the state to strive to ensure living wages, conditions of work ensuring decent standard of life. The Article further requires the state to ensure that workers attain full enjoyment of cultural opportunities. Thus, this section is broad in the sense that it covers not the monetary aspect of life, but also the cultural aspect.

The Supreme Court while dealing with the issue of wages for the workmen has held that wage so provided to every workman shall ensure him highest level of industrial efficiency. The court further observed that, the wage so provided shall enable the workmen to provide material thing which will enable them to ensure material things to their families. ${ }^{\text {lxii }}$ It is therefore in this utopian sense that Article 43 of the constitution refers to living wage and not basic wage, as the former includes in addition to bare minimum necessities, provisions for insurance, children education etc.

The court in Poly Chem Ltd. v. R.D. Tulpule, Industrial Tribunal Bombay, lxxiii the court while dealing with question of wages in the backdrop of Part IV of the constitution of India, held that a wage structure shall ensure fair remuneration and fair return to capital, social dignity, incentive to efficiency, without prejudicing the expectations and interest of consumers. 
International Journal of Social Science and Economic Research

ISSN: 2455-8834

Volume:05, Issue:10 "October 2020"

\section{COVID 19 IMPACT ON UNORGANISED SECTOR}

The COVID19 lockdown brought another humanitarian tragedy in the lives of unorganized sector workers or the migrant workers. The unorganized workers combined with informal workers of the organized sector constitute more than $90 \%$ of the total workforce in India. ${ }^{\text {lxiv }}$ The workers of this sector are people with minimal means and have to even battle for their daily meals. The lockdown which involves closure of factories/establishments, travel restrictions and sealing of interstate borders, would be as challenging as the COVID-19 itself. Various organisations including the International Labour Organization (ILO), estimated that over 25 million jobs could be lost due to the economic impact of this COVID-19 pandemic. However, the ILO while describing the COVID-19 as one of the worst catastrophe reported that the figures can be even more than the initial ILO projection of 25 million. ${ }^{1 \times x v}$

The impact of the outbreak is going to be more devastating for the unorganized sector due to lack of adequate social security measures like paid leaves, minimum wages, gratuity etc. Due to evaporation of work, the loss of job will be accompanied with significant decline in the income level of workers, and more specifically for the workers in the unorganized sector. This impact of this pandemic on the unorganized sector was visible, even prior to the lockdown after the initial measures of social distancing were set in. The work evaporated as establishment started shutting in various states, forcing migrant workers to return back to home. This exodus of workers which was caused due to loss of work and lack of any income support was further intensified after the complete lockdown of the country, thereby paradoxically frustrating the purpose of social distancing.

\section{International Labour Organisation}

The ILO ${ }^{\mathrm{lxxvi}}$, since its date of inception has been constantly contributing and working towards formulation of standards so as to extend benefits of social security to greater number of people in case of various contingencies. The Philadelphia declaration casts an obligation upon to attain "the extension of social security measures to provide a basic income to all in need of such protection and comprehensive medical care."1xxvii The Treaty of Versaills, 1919 gave a broad mandated to ILO to formulate International Labour standards. The standards set by ILO are to be universally applied so as to ensure social justice to the workers and to improve the working conditions of the workers.

\section{CONCLUSION AND SUGGESTIONS}

The need for social security for labour is not felt today rather such has been considered by the Government since the enactment of Constitution. It was clear from that point that safeguarding 


\section{International Journal of Social Science and Economic Research}

ISSN: $2455-8834$

Volume:05, Issue:10 "October 2020"

interests of labour is necessary for achieving rapid economic growth. Post- constitutional phase witnessed the formulation of several social security legislations which introduced several benefits in favour of labour employed in the organised sector. The motive behind this step by the Legislature at that time was the adoption of tri-partism in the industrial relations in view of the model laid down by the International Labour Organization.

Since then, the legislature as well the government has been to some extent been able to deal with the requirements of the labour but such was constrained to organized sector. This resulted in widening gap amongst the labour and the categorization of organised and unorganised labour acted more as discrimination. The legislature, governments, policy- makers and other relevant authorities failed to consider the growth of unorganised sectors and labour therein and their contribution to the GDP of the nation. The Report of National Commission for Enterprises in Unorganized Sectors (2006) confirmed that a substantial percentage of GDP is contributed by such sectors while nothing is done on the bureaucratic part for providing the workers deprived even of their basic rights and many a times they are not even provided with the minimum wages as had been laid down by the MWAct which adds to their misery. Thus, it is the time to formulate a robust mechanism in order to ensure social security of labour in these sectors.

The Government has since independence constituted several High Commissions and Committees to provide with the plight of labours in these sectors to which even such commissions and committees provided adequate conclusions and suggestions but the same were never provided with a statutory backing or the bureaucratic support and thus, while considering history it can be said that such committees and commissions were a futile exercise and never resulted in anything fruitful in relation to the benefits of labour in unorganized sectors.

Now, from the point of view of judiciary, there is not much opportunity been accorded to it to deal with the matters of unorganized sector and it is because their claims could not reach court because of various contributory factors including illiteracy and poverty as their survival is dependent on the daily wages and cannot stand to the court's scrutiny time and again.

The Supreme Court however, has held while enlarging the scope of the Right to Life enshrined under Article 21 of the Constitution, that such right includes right to decent working conditions. But it did not go any further and hence, the miserable position of unorganised labour could never be provided justice and freedom from the shackles of exploitation and low wages. Thus, including several labour specific legislations even the constitutionally provided fundamental rights cannot be exercised by the labour in such sectors. Moreover, in relation to such labour, the provisions provided under the Directive Principles of State Policy of the Constitution merely acts as a mere- legislation on paper. 


\section{International Journal of Social Science and Economic Research}

ISSN: $2455-8834$

Volume:05, Issue:10 "October 2020"

In this study, several schemes on the part of government both at Central and State level which provide benefits to the downtrodden sections of the society but when such schemes have been analysed in view of effectiveness of the implementation, it is clear that such schemes generally were not formulated to benefit the backward section of the society rather as a political tactic for improving vote-banks by the politicians. Moreover, the flawed criterion of estimating BelowPoverty-Line is another subject which is required to be dealt with.

In addition, whenever the Legislature or Government is asked to step-in to resolve the issues faced by the society, every-time it results in establishment of a new authority and is related to a different ministry of government and department. Such practise encourages the lethargic behaviour amongst these authorities which are not provided with any substantial powers and the claims of the benefactors stand upon the receipt of approval from the ministries.

The stagnant position of unorganized labour will continue till a national social security policy or legislation is formulated and these authorities are accorded with certain powers and thereby, the diffusion of energy and resources will be kept under check.

Thus, there are existing social security measures within various central and state legislation that can help workers across the country. This is become more important during unprecedented situation like the present pandemic of COVID-19. However, the larger problem that makes these legislations a toothless tiger is the inability and unwillingness of the state authorities to effectively implement the schemes and policies so formulated. COVID-19 outbreak provides an opportunity for the state to expand the scope and reach of these existing social security measures by utilizing the available resources and welfare funds, so as to ensure social security to the vulnerable section of the society. The Central and the State Government shall take proactive steps to honor the mandate provided to them under the UWSS Act and the BOCW Act by formulating new schemes and by ensuring their effective implementation. One of the limitation of all the existing social security measures remain poor or very low number of registration. Therefore, the government shall devise innovate design for expansion and proper implementation of these schemes.

Nonetheless, it becomes imperative on the state authorities to devise new schemes and to ensure effective implementation of the existing schemes so as to realize the object of a welfare state and to honor the mandate of Right to life. ${ }^{\text {lxxiii }}$ Pandemic, like COVID-19 is nothing less than a war and the government shall thus mobilize its resources to prevent a greater harm. The aim during these times should be to flatten the COVID-19 curve but, to steepen the learning curve and to utilize the learning in understanding the plight of workers to aid and support them during contingencies. 


\section{International Journal of Social Science and Economic Research}

ISSN: $2455-8834$

Volume:05, Issue:10 "October 2020"

\section{SUGGESTIONS}

1. The legislations which are merely on paper are required to be effectively implemented in order to safeguard the interests of labour and the accountability of the relevant authorities is required to be increased. One of the significant reason behind such ineffective enforcement is the lethargic behaviour of the enforcement bodies and thus, disciplinary action shall be called for against such officials who are not able to dispense the functions $f$ their office properly.

2. A large chunk of labour in India is employed in un-organized sectors whereby they are not provided with certain statutory reliefs and unable to deal with the inevitable adverse situations. Thus, it is suggested that the Central Government shall after coordinating with the relevant authorities in each state shall extend the applicability of certain legislations like ESI Act and EPF Act to all such sectors after making suitable amends to the original legislation. Moreover, the ambit of National Assistance Programmes needs to be enhanced in order to extend benefits of maternity, pension and other benefits to the such sectors.

Now, only the extension or formulation of a special scheme would not serve the object of social security until it is effectively and efficiently implemented and the benefits meant for such labour is provided to them. In other words, the law shall not only be on letter but also in spirit.

3. In order to extend coverage of the above-mentioned schemes to the unorganized sectors, the recommendations of the International Labour Organization can be referred to and applied in the Indian scenario after making suitable modifications.

4. Moreover, the quantum of benefits provided under the said schemes need to be revisited by the Legislature as well as Central and State Governments as majority of such schemes stand redundant in present times considering the inflation.

5. In relation to lay-offs, retrenchment compensation and closure of establishment under the provisions of Industrial Disputes Act, 1947, it is suggested to reduce the minimum threshold to twenty from fifty in order to bring more of labour working in factories and industries within the realm of the provisions of the said Act and thereby, provide them with job-security.

However, the legislation shall rather than focusing on establishment of a new authority for its effective implementation shall delegate such work to the already established authorities with increased accountability in order to keep a check on effective implementation of the said legislation. 


\section{International Journal of Social Science and Economic Research}

ISSN: $2455-8834$

Volume:05, Issue:10 "October 2020"

6. Moreover, the definitions of terms "unorganised sector" and "unorganised worker" needs to be removed from several labour enactments in order to provide with effective implementation of the social security schemes and placing all workers on the same pedestal with equal safeguards and benefits. In order to deal with this situation, the recommendation provided by the National Commission of Labour in 2002 shall be followed which provided to enlist all the types of labour activities wherein such workers are employed.

7. A simple process is required to be formulated for obtaining registration of labour working in the unorganized sectors. The registration shall be done at district levels and in order to spread awareness in this regard, the assistance of the Non-Government Organizations and Trade-Unions which are working for safeguarding interests of such labour, can be sought.

8. In addition, skill upgradation is also required on the part of labour in order to work in several industries, hence, it is suggested that the Government shall formulate a structure and provide periodical skill trainings to all kinds of labour in order to meet the challenges of the upcoming automation in industries.

9. In light of the COVID-19 pandemic and the plight migrant workers are suffering since lockdown calls for formulation of a National Social Security Policy with a clear aim and objectives it seeks to achieve. Under the said policy, a legislation would be required to be enacted by the Parliament which should clearly identify the players involved in formulation, enforcement, supervising and evaluating the national programmes providing social security to the labour.

10. During the COVID-19 crisis, the government shall aim at effective utilization of the funds collected under various legislations like the construction worker welfare fun or the ESIC fund and shall ensure direct transfer of these funds to the workers, especially the unorganized or informal labourers who are worst hit from this pandemic.

It is evident that effective and efficient workforce plays a major role in the growth of the economy and the present situation is appropriate to overhaul the system of labour laws and safeguard the interests of Indian workforce which could result in expedient growth of the economy. The COVID-19 has clearly depicted the importance of labour workforce in India and the significance they carry in the economic growth. Now, when the objective of Indian government is to revive, be self-reliant and to be a welfare State, such can only be achieved when a balance is maintained between the interest of the industry and labour. 
International Journal of Social Science and Economic Research

ISSN: 2455-8834

Volume:05, Issue:10 "October 2020"

\section{References}

${ }^{i}$ Universal Declaration of Human Rights Article International Covenant of Economic, Social and Cultural Rights

ii Jose Maldonado Member, Paper: "Social Security and Income Security in USA"

iii Government of India, Draft Labour code on social security , 2018, p. 57

${ }^{\text {iv }}$ Government of India, Report of National Commission on Labour, (1969), Chapter 12 p.162.

${ }^{v}$ International Labour Organisation, DG Reports Available at https://www.ilo.org/wcmsp5/groups/public/---

dgreports/ dcomm/documents/publication/wcms_067588.pdf (Last accessedon Macrh, 24 , 2020)

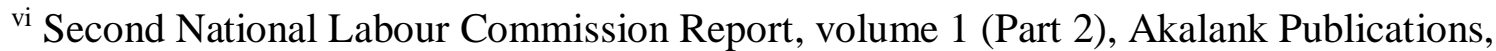
October, 2002,

pg 792.

vii The Social Security (Minimum Standards) Convention 102

viii Deepak Bhattnagar, Labour Welfare and Social Security Legislation in India Deep \& Deep Publications

1984 Edition pg.46-47.

ix Cambridge Dictionary, Available at :

https://dictionary.cambridge.org/dictionary/english/social-security

${ }^{x}$ Merriam Webseter Dictionary, Available at :https://www.merriamwebster.com/dictionary/social\%20security

xi Narendar Jetly - India: Man Power, Employment Policy and Labour Welfare, 1947-2007 New Century Publications) 2006 Edition pg.120-121.

xii Government of India, 1st Five Year Plan, (1951-1956), Chapter 34 Pg. 12 Para 4.

xiii Supra note 2, at para 45. 
${ }^{\text {xiv }}$ Government of India, ${ }^{\text {rd }}$, Five Year Plan (1961-1966) pg..9-10

${ }^{x v}$ Government of India, $2^{\text {nd }}$, Five Year Plan, (1956-1961) para 20.

xvi Ibid, at para 26.

xvii Ibid, at para 38

xviii Ibid, at para 24

${ }^{x i x}$ National Commission on Labour Report, (1969), pg.164.

${ }^{x x}$ Supra Note 4, at 258

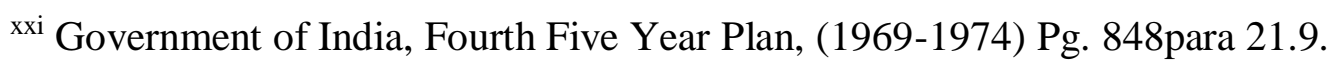

xxii Ibid, at para 22.1

xxiii Draft $5^{\text {th }}$ Five Year Plan (1974-1979) Vol.2, p.273

xxiv Ibid

${ }^{\text {xxv }}$ Government of India, $6^{\text {th }}$,Five Year Plan, (1980-1985) pg.405

xxvi Ibid

xxvii Ibid, at para 29.41

xxviii Ibid, at para 24.4

xxix Ibid, at para 24.36

${ }^{x x x}$ Government of India, $7^{\text {th }}$,Five Year Plan, (1985-1990) para 5.63

xxxi Jetli, Supra note 1, at 330 .

xxxii A.M.Sarma, Welfare of Unorganised Labour, Himalaya Publishing House 2008 Edition Pg..30 - 32

xxxiii Government of India, 10 ${ }^{\text {th }}$ Five Year Plan, (2002-2007) para 3.5.7. 
xxxiv Ibid., at para 3.5.2.

${ }^{x x x v}$ Ibid., at para 3.5.5

${ }^{\text {xxxvi }}$ Government of India, $11^{\text {th }}$, Five Year Plan (2007-12), pg.153.

xxxvii $12^{\text {th }}$ Five Year Plan (2012-2017) p.169

xxxviii Ibid., at 169.

${ }^{\text {xxxix }}$ Ibid, at 167

${ }^{x l}$ Ibid

xli Ibid., at 175.

xlii Government of India, India Three Year Action Agenda (NITI Aayog, 2017) Available at https://niti.gov.in/writereaddata/files/coop/IndiaActionAgenda.pdf xliii Employee Compensation Act, 1923 (Act 8 of 1923)

${ }^{\text {xliv }}$ Fatal Accident Act, 1977 (Act 17 of 1977)

${ }^{x l v}$ C.S. Azad, University of Agri. and Tech. v. Court of Workmen Compensation Commissioner, 2003 Lab I C 140 Allahabad.

${ }^{\text {xlvi }}$ Oriental Insurance Co. Ltd. v. Mohd.Nasir (2009) 6 SCC 280.

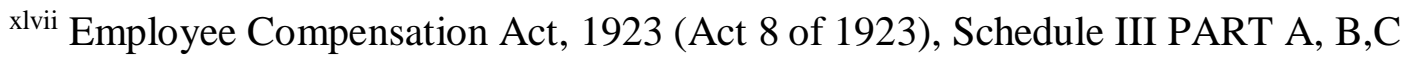

xlviii Section 1 (4) r/w Section 2(12) of the ESI Act, 1948 (Act 34 of 1948)

xlix The Employees State Insurance Act 1948 (Act 34 of 1948),

${ }^{1}$ Section 19 of the ESI Act states that "the Corporation may, in addition to the scheme of benefits specified in this Act, promote measures for the improvement of the health and welfare of insured persons and for the rehabilitation and re-employment of insured persons."

${ }^{\text {li }}$ Rule 56 of E.S.I. (Central) Rules, 1960, w.e.f. 1.2.1991. 
lii ESI Regulations: 87, 88, 89, 89A, , 90- 95.

liii Rule 59 of E.S.I. (Central) Rules 1950 as amended by ESI (Central) (Amendment) Rules, 2011 w.e.f. 1.4.2011

liv The Employees' Family Pension Scheme, 1971

${ }^{\text {Iv }}$ Employees' Pension Scheme, 1995

lvi Employees’ Deposit Linked Insurance Scheme, 1976

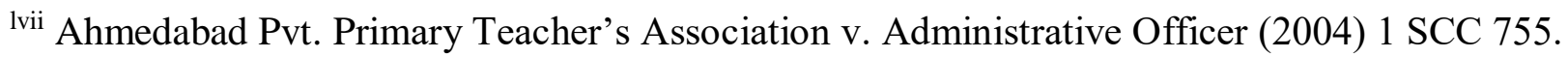

lviii Payment of Wages Act, 1936 (Act 4 of 1936); Section 3

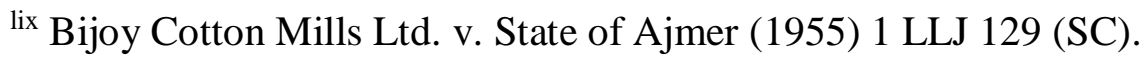

${ }^{1 x}$ Payment of Wages Act, 1936 (Act 4 of 1936); Section 26(1).

Ixi Ibid, at Section 3(2).

lxii Ibid., at Section 3(3)

Ixiii Report of the National Commission for Enterprises in the Unorganised Sector, The Challenge of Employment in India, Vol.I, 2009, p.147.

lxiv The Unorganised Workers Social Security Act, 2008 (Act 33 of 2008); Section 2(m)

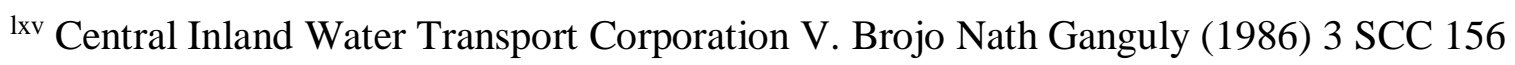

${ }^{\text {lxvi }}$ Constitution (44th Amendment) Act, 1978

Ixvii The Constitution of India, Article 38(2)

Ixviii AIR 1997 SC 645

${ }^{\text {lxix }}$ AIR 1982 SC 879

${ }^{1 \times x}$ AIR 1997 SC 699

${ }^{\text {Ixxi }}$ Municipal Corporation of Delhi v. Female Workers, AIR 2000 SC 1274. 
International Journal of Social Science and Economic Research

ISSN: 2455-8834

Volume:05, Issue:10 "October 2020"

lxxii Standard Vacuum Refining Co. of India v. Workmen, AIR 1961 SC 895

1xxiii AIR 1972 SC 1967

lxxiv Government of India, Ministry of Labour and Employment "Employment in Informal Sector and Conditions of Informal Employment" (2014-15)

${ }^{1 x x v}$ International Labour Organization, Press Release : “ COVID 19 causes devastating losses in working hour and employment” Available at : https://www.ilo.org/global/about-the-

ilo/newsroom/news (Last visited on 10 April, 2020)

${ }^{1 x x v i}$ ILO has developed the code of international Labour Standard which consists of various conventions recommendations. Lee Swepston, "The Future of ILO Standards", 117 Monthly Lab. Rev. 16

lxxvii Philadelphia Declaration of 1944, "ILO DeclarationConcerning Aims and Purposes of ILO" International Labour Office, 25 Official Bulletin 1 (1944)

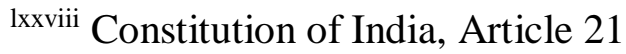

